"Test by the SVECM model of the impact of the exchange rates and foreign direct investment on the economic growth of the Maghreb region"

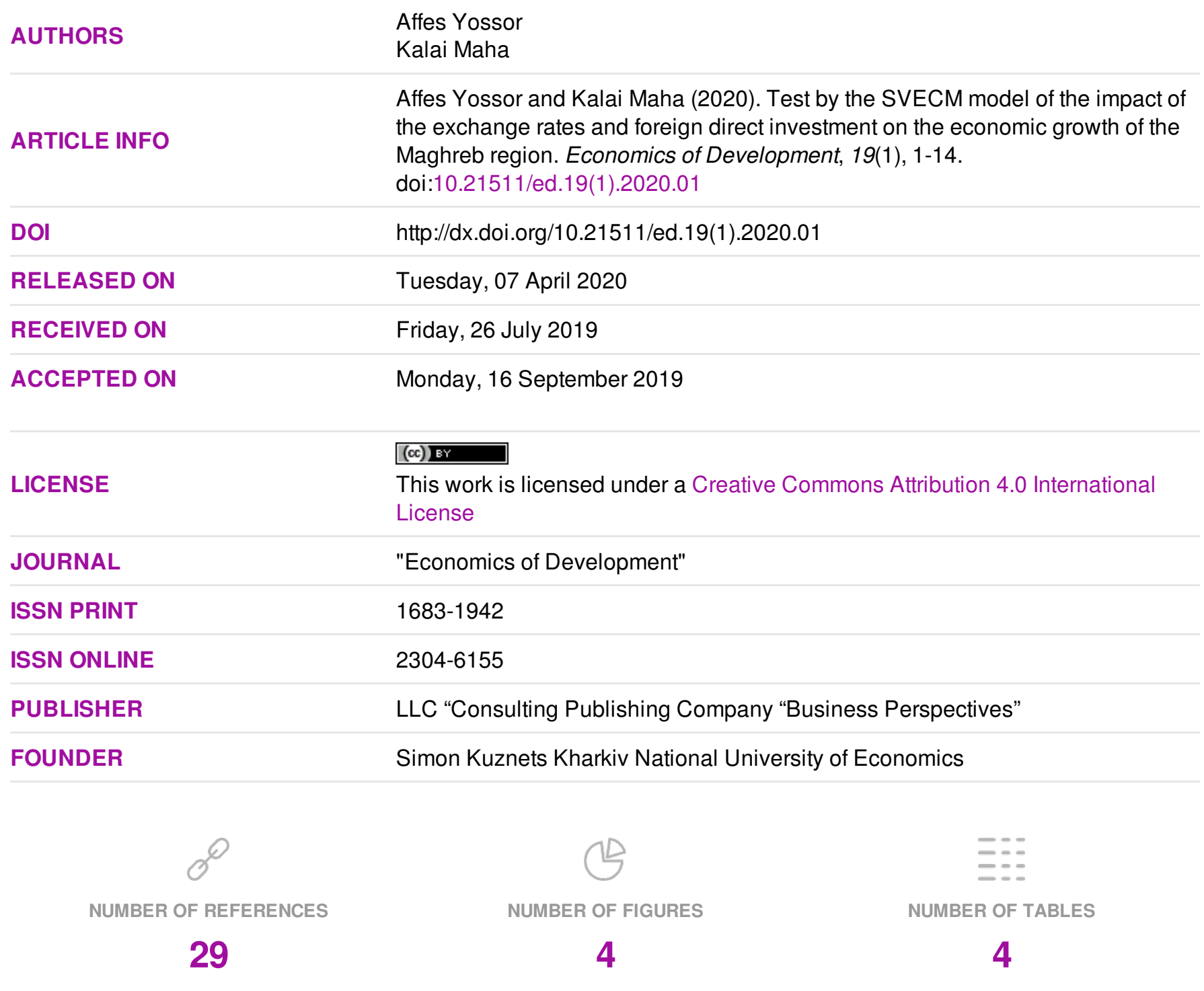

(c) The author(s) 2021. This publication is an open access article. 


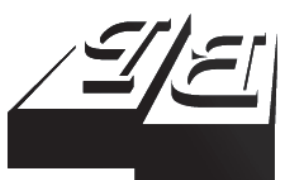

BUSINESS PERSPECTIVES

Publisher

LLC "CPC "Business Perspectives" Hryhorii Skovoroda lane, 10, Sumy, 40022, Ukraine www.businessperspectives.org

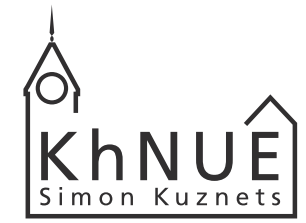

S. KUZNETS KHNUE

Founder

Simon Kuznets Kharkiv National University of Economics, Nauky avenue, 9-A, Kharkiv, 61166,

Ukraine

http://www.hneu.edu.ua/

Received on: 26th of July, 2019 Accepted on: 16th of September, 2019 Published on: 7th of April, 2020

() Affes Yossor, Kalai Maha, 2020

Affes Yossor, Assistant Professor in Economics, Faculty of Economics and Management, University of Sfax, Tunisia.

Kalai Maha, Assistant Professor in Quantitative Methods, Faculty of Economics and Management of Sfax, University of Sfax, Tunisia.

\section{(c) (1)}

Th $\mathrm{s}$ is an Open Access article, distributed under the terms of the Creative Commons Attribution 4.0 International license, which permits unrestricted re-use, distribution, and reproduction in any medium, provided the original work is properly cited.

Affes Yossor (Tunisia), Kalai Maha (Tunisia)

\title{
TEST BY THE SVECM MODEL OF THE IMPACT OF THE EXCHANGE RATES AND FOREIGN DIRECT INVESTMENT ON THE ECONOMIC GROWTH OF THE MAGHREB REGION
}

\begin{abstract}
The purpose of this article is to identify the main sources of cyclical fluctuations affecting the five Maghreb countries in a general analysis framework through the impact of the exchange rates and foreign direct investment. Besides, will consider in this study a set of variables taking into account the real monetary and fi ancial dimensions of the economies. Therefore, authors have adopted an approach in terms of the VECM Structural model and analyzed the robustness of the response functions. Indeed, the estimation results showed the existence of a regional dynamics where the respective sensitivity to change of the real exchange rate is the same. In addition, FDI and REER stimulate economic growth of the Maghreb economies in exchange for regime transmutations. In addition, the participation of FDI in the socio-economic development seems to be weak without the implementation of a policy of support and guidance aimed at reducing the catastrophic effects on the economy and reorienting its investments towards sectors with a high added value.
\end{abstract}

Keywords

JEL Classification

structural VECM, demand and supply shocks, economic convergence, Maghreb countries

F15, F42, F43, C32

Аффес Йоссор (Туніс), Калай Маха (Туніс)

\section{АНАЛІЗ ВПЛИВУ ОБМІННОГО КУРСУ ТА ІНОЗЕМНИХ ПРЯМИХ ІНВЕСТИЦИЙ НА ЕКОНОМІЧНЕ ЗРОСТАННЯ КРАÏH МАГРИБУ 3 ВИКОРИСТАННЯМ СТРУКТУРНОÏ ВЕКТОРНОÏ МОДЕЛІ КОРЕКЦІЇ ПОХИБОК}

\section{Анотація}

Мета статті - визначити основні джерела циклічних коливань, які впливають на розвиток п’яти країн Магрибу, шляхом аналізу впливу обмінних курсів і прямих іноземних інвестицій Крім того, проаналізовано набір змінних з урахуванням реальних грошових і фінансових вимірів економічних систем. Для аналізу надійності функції віддачі використано структурну векторну модель корекції похибок. Результати вказали на наявність регіональної динаміки, коли відповідна чутливість до зміни реального обмінного курсу є однаковою. Виявлено, що прямі іноземні інвестиції та реальний ефективний валютний курс стимулюють економічне зростання економіки Магрибу в обмін на режимні зміни. Крім того, роль ПІІ в соціальноекономічному розвитку виявляється слабкою через відсутність політики підтримки та наставництва, спрямованої на зменшення катастрофічних наслідків для економіки та переорієнтацію інвестицій на сектори з високою доданою вартістю.

Ключові слова

Класифікація JEL структурна модель векторної корекції похибок, попит і пропозиція, економічна конвергенція, країни Магрибу F15, F42, F43, C32 


\section{INTRODUCTION}

The purpose of this study is to focus on two types of determinants of macroeconomic stability as captured by some fundamentals of the host economy (economic growth, stability, business climate, political stability, country risk, sustainability of the public debt, inflation, ...) but similarly by the episodes of foreign exchange crisis that can be explained more by speculative attacks, reversals of capital flows, massive losses of foreign reserves and foreign exchange reserves and/or the deterioration of current accounts and which reflect external instability.

These debts to foreign countries cannot be settled in national currency (which does not exist abroad), but in foreign currency (paid in cash, by cheque, by bank drafts and especially transfers in foreign currency) that the debtor must obtain in his country by exchanging it for a certain amount of the national currency (Burda et al., 1993). This process of transfer is made possible through a tool known as the exchange rate.

Moreover, the exchange rates are at the heart of the international economic relationships and an integral part of the daily landscape of the economic agents. In fact, the rise of the international trade and financial relationships as well as the independence that results from it, are a first element explaining the strategic importance of this variable (exchange rate). Beyond its economic and financial dimension, the exchange rate plays a fundamental role as an instrument or an objective of the economic policy, or even as a symbol of political power.

Therefore, it was noted that there are two macroeconomic dimensions of country risk, which concern, on the one hand, internal factors, such as the characteristics of inflation, debt and the reduction of public deficits when they worsen, which can negatively influence the firms' decisions to invest by creating conditions of uncertainty about asset values or future taxation and, on the other hand, they concern external factors, such as external asymmetric shocks (imported crises), current account deterioration or exchange rate instability, which bring about similar levels of contingency.

In relation to what has been previously said, the question that arises is to what extent the main sources of cyclical fluctuations in the real effective exchange rate and foreign direct investment can influence the behavior of economic growth in the Maghreb countries?

To address this issue, our work is organized as follows: the second section consists in a presentation of the status of empirical research studies which help identify the causal relationships between economic growth, the exchange rate and foreign direct investment on panel data. Next, an overview of the data, the variables and the estimation techniques is presented in the third section. The fourth section introduces an econometric application based on the Structural Vector Auto-Regression (SVAR). Finally, the last section concludes this research paper.

\section{THEORETICAL ANALYSIS}

Given the theoretical development mentioned above, it can be noticed that the consequences of applying the exchange rate regimes are various and sometimes opposite, while the final effect is not obvious to be determined a priori.

\subsection{Economic growth and exchange rate}

The majority of the conducted empirical studies are based on the IMF's certified hierarchy of the exchange rate regimes. However, these studies did not generate strong claims about the effect of the exchange rate nature on the economic development, which encouraged researchers to use new classifications. For this reason, Bailliu et al. (2001) used their own scale to study a sample of 25 emerging economies between 1973 and 1998, through which they noted that floating exchange rate regimes lead to a faster economic development, but only for countries that are highly correlated with international capital flows or affected by well-developed financial markets. 
Based on the methodology of Reinhart and Rogoff (2004), Husain et al. (2004) found, on a sample of 158 countries between 1970 and 1999, that the chosen exchange rate regime results mainly from the level of economic development. Subsequently, for the developing countries, a rigid exchange rate regime is often accompanied with a low inflation rate but without an impact on economic growth while the adoption of a flexible exchange rate regime by the same countries will raise the inflation rate without any improvement of economic growth. On the other hand, for the developed countries, estimates showed that a greater exchange rate flexibility leads to a low inflation rate and a significant economic growth.

In order to address these deficiencies, researchers, including Levy-Yeyati and Sturzenegger (2002) and Reinhart and Rogoff (2004), presented new classifications of foreign direct investment (FDI) based primarily on the exchange rate flexibility. In fact, the change of the exchange rate calculated as the standard deviation of the monthly rates of the change of the nominal exchange rate and finally, the fluctuation of the foreign exchange reserves calculated by the average of the monthly exchange rate of the ratio of the world reserves compared to the monetary base of the previous month.

From another angle, researchers Dehejia and Rowe (1999) and Dehejia (2003) agree on the division of the traditional methodology into three aspects, which makes it possible to distinguish between fixed, intermediate and floating exchange rates where the last two simply define the exchange rate regime, while the first characterizes both the exchange rate regime and the monetary policy framework. In fact, omitting this characteristic may alter the estimation of the impacts of the different exchange rate regimes on macroeconomic observations.

\subsection{Economic growth and foreign direct investment}

In fact, according to the endogenous growth theory, several factors, such as human capital, capital accumulation, international trade, public policy, and technology transfer, which explain a long-term growth, can be conveyed by FDI, which can stimulate economic growth through the creation of dynamic comparative advantages leading to technology transfer, human capital accumulation and increased international trade (Bende-Nabende et al., 2003; Bende-Nabende, 2002). These dynamic benefits, which are linked to one another, are complementary and therefore do not need to be studied separately. Actually, the gain generated by the EDI on one growth factor is likely to stimulate the development of the other factors, thus forming some kind of synergy.

On the other hand, trade flows and FDI are well known as very important factors in the process of economic growth. In fact, trade plays the role of upgrading skills through the importation and adoption of a superior production and innovation technology. If exporters use the innovation and production technology developed either by acting as sub-contractors for foreign companies or by competing on international markets, import producers face competition from foreign companies. They are pushed to adopt capital-intensive production facilities to face stiff competition from the developing countries where products are generally capital-intensive (Frankel and Romer, 1999). Therefore, the impact of trade openness on economic growth can be positive and significant mainly due to the physical capital accumulation and technology transfer.

Most of the previous empirical studies have dealt either with the effect of the interaction between trade and FDI on economic growth (Selmi et al., 2016) or with the relationship between FDI and economic growth (Lipsey, 2000) and/or between trade and economic growth (Pahlavani et al., 2005). All these studies concluded that both FDI flows and trade promote economic growth. However, they could not provide a conclusive result on the relationship in general and on the meaning of causality in particular in many developing countries. In fact, the increased effects of FDI and trade flows may vary from one country to another and over time. In some countries, FDI and trade can even negatively affect economic growth $(\mathrm{Xu}, 2000)$.

According to an IMF study, Dabla-Norris and Lahreche (2010) studied the effect on economic growth for a heterogeneous group of countries. In fact, for the intermediate and poor but non-oil economies, FDI recorded a significant impact between $0.5 \%$ and $0.7 \%$ of growth following an increase of the FDI/GDP ratio of $1 \%$. However, oil-producing countries have had little or no effect of FDI on growth, regardless of their inflow. This shows a strong acceleration of FDI for several years, followed by a stronger impact on growth, as if, because of the entry into a new period. 


\section{EMPIRICAL METHODOLOGY: MODEL, VARIABLES AND ESTIMATION TECHNIQUES}

Authors purpose here is to see whether the real effective exchange rate (REER) and FDI could have a significant effect on the economic growth of the countries of the Maghreb region during the recent period, characterized by a floating exchange rate regime. While the exchange rate may be considered exogenous at the firm level, this assumption is questionable at the macroeconomic level. Since authors are interested in macroeconomic relations, the exchange rate and investment should be treated as interactive variables. In addition, given the prospective nature of investment decisions, it is important to use a framework that allows for a more detailed dynamic analysis.

To account for both feedback effects and dynamic effects, for our analysis chose a structural Vector AutoRegression (SVAR) model. In the context of VAR models, all variables are considered endogenous, and the analysis of dynamic structures can take many different forms. An autoregressive representation makes it possible to apply Granger causality tests, while a moving average representation is used to estimate dynamic responses to shocks. Although these two types of effects are related, their review provides separate and complementary information. In fact, the structural VAR methodology allows in addition to simulate structural shocks.

\subsection{Model specification}

After a brief overview of the empirical literature and the theoretical and adaptation foundations of a structural linear dynamic model, will now focus on the appropriate empirical specification of this model in order to resolve our problem.

In Solow's model, the increase of the production factors (labor and capital) accounts for some of the growth. Since there is an increase of the labor force (labor factor) and domestic investments (capital factor) there is growth. Hover, most of the growth is not explained by these two factors, but is due to a residual factor. This is technical progress the origin of which is not really known (some say it is a factor "fallen from the sky").

Other than labor (salaried employment, POP) and capital (Gross Fixed Capital Formation, GFCF as a percentage of GDP), the other explanatory variables can be presented in three groups. Our approach consists the, in using three groups of variables in which the estimation, which was carried out between 1980 and 2016, has become efficient through the use of the criteria of absence of residuals autocorrelation and individual and temporal heteroskedasticity. Indeed, the first group of explanatory variables includes the variables relating to economic policy, namely:

- first, public spending relative to the real GDP $(G)$;

- second, foreign direct investment relative to the real GDP (FDI);

- then, trade openness in relation to real the GDP (TRADE);

- finally, the consumer price index (CPI).

It was shown that the bidirectional causality report between investment and growth is very important for an open economy. Therefore, investing in a country rather than abroad generates prospects for investment returns, which refers to domestic opportunities opened up by growth.

The second group of explanatory variables forms monetary variables related to GDP, namely:

- $\quad$ on the one hand, the monetary aggregate (M3);

- on the other hand, private credit (CREDIT), which represents the degree of development of the financial sector, whose expected positive effects on growth.

The third group of explanatory variables forms exchange rate variables, namely:

- the real effective exchange rate (REER).

In the existing literature, a distinction is made between the short- and long-term effects of shocks. Indeed, real supply shocks are defined as exogenous changes in commodity prices or energy prices, production shocks or wage prices. Real demand shocks collect unanticipated changes in consumption, investments or public spending. 


\subsection{Presentation of the countries studied and descriptive analysis of the variables}

The purpose of this section is to describe the sample and provide a descriptive analysis of the variables per country. In fact, our Panel comprises N=5 Maghreb countries, namely Algeria, Morocco, Mauritania, Libya and Tunisia between 1980 and 2016, see 37 observations per country. Indeed, and based on the statistics presented in Table 1, authors will describe the main characteristics of the main variables used in this study.

Table 1. Overall descriptive analysis of basic variables

Source: Author's calculations

\begin{tabular}{|c|c|c|c|c|c|c|c|c|c|c|}
\hline Designation & GDPC & POP & GFCF & FDI & REER & CPI & TRADE & M3 & G & CREDIT \\
\hline Average & $35,269.74$ & $4,190.976$ & 29.05 & 2.13 & 124.75 & 74.11 & 78.41 & 58.74 & 70.42 & 35.60 \\
\hline Median & $6,514.48$ & $2,334.780$ & 27.48 & 0.94 & 104.07 & 77.74 & 64.72 & 51.94 & 75.38 & 29.03 \\
\hline Maximum & $179,193.80$ & $12,541.810$ & 70.48 & 37.17 & 447.53 & 182.84 & 224.69 & 253.91 & 149.00 & 81.16 \\
\hline Minimum & 966.47 & 425.676 & 9.48 & 0.00 & 30.01 & 8.98 & 25.63 & 18.36 & 26.64 & 3.91 \\
\hline Standard Deviation & $56,978.17$ & $3,888.350$ & 11.37 & 4.26 & 70.83 & 37.78 & 38.94 & 34.77 & 16.36 & 21.04 \\
\hline Skewness & 1.52 & 0.88 & 1.16 & 5.16 & 2.30 & 0.23 & 1.49 & 2.11 & 0.16 & 0.47 \\
\hline Kurtosis & 3.49 & 2.20 & 5.04 & 35.56 & 9.32 & 2.48 & 5.20 & 10.15 & 6.68 & 1.93 \\
\hline Jarque-Bera (JB) & 73.35 & 29.02 & 73.44 & $8,991.21$ & 471.66 & 3.72 & 105.82 & 531.16 & 105.18 & 15.60 \\
\hline JB Probability & 0.00 & 0.00 & 0.00 & 0.00 & 0.00 & 0.16 & 0.00 & 0.00 & 0.00 & 0.00 \\
\hline Observations & 185 & 185 & 185 & 185 & 185 & 185 & 185 & 185 & 185 & 185 \\
\hline
\end{tabular}

According to the Figure 1 shows a significant increase of FDI from the mid-2000s to the end of the sample period. During the 1980/2016 period, the evolution of FDI in this country was assessed at an average of 5.39 with a standard deviation of 8.34. The set of logarithmic values was between 0.01 and 37.17. Therefore, the sample distribution of FDI is asymmetrically spread on the right (Skewness=2.38) and strongly leptokurtic (Kurtosis=5.88). Based on the probability of the Jarque-Bera's normality test, authors reject the null hypothesis of normality at $5 \%$. Overall, this variable shows a significant overall growth of $49.72 \%$ with an annual growth of $1.13 \%$.

For the real effective exchange rate (REER), the evolution of the 5 countries in the Figure 2 shows a clear difference until the beginning of the 1990s and thereafter observe the stability of the rates around $100 \%$. For the case of Tunisia, the evolution of the REER is characterized by an average of 133.5 with a standard deviation of 41 . The set of values is between 94.8 and 220.2. The sample distribution of the TCER is asymmetric spread on the right

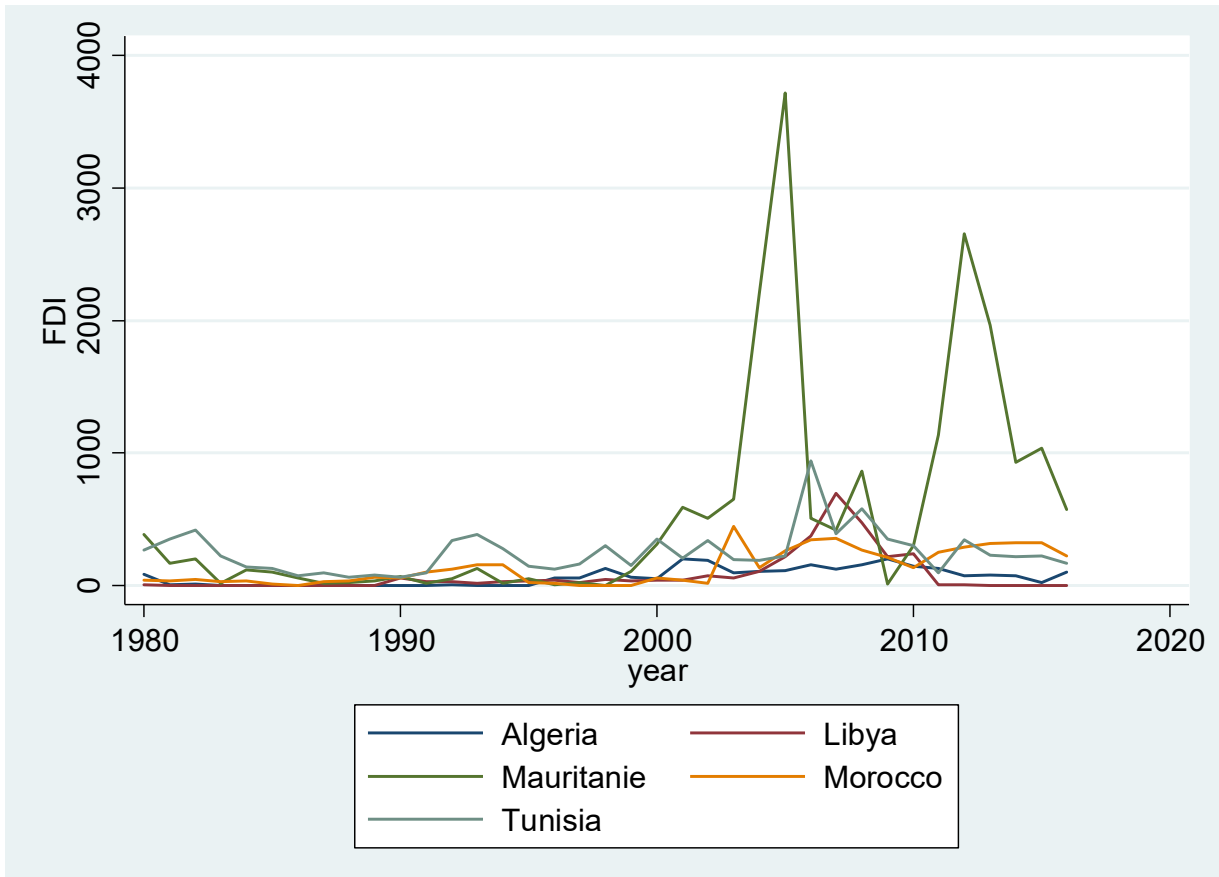

Figure 1. Trend evolution of FDI per country 


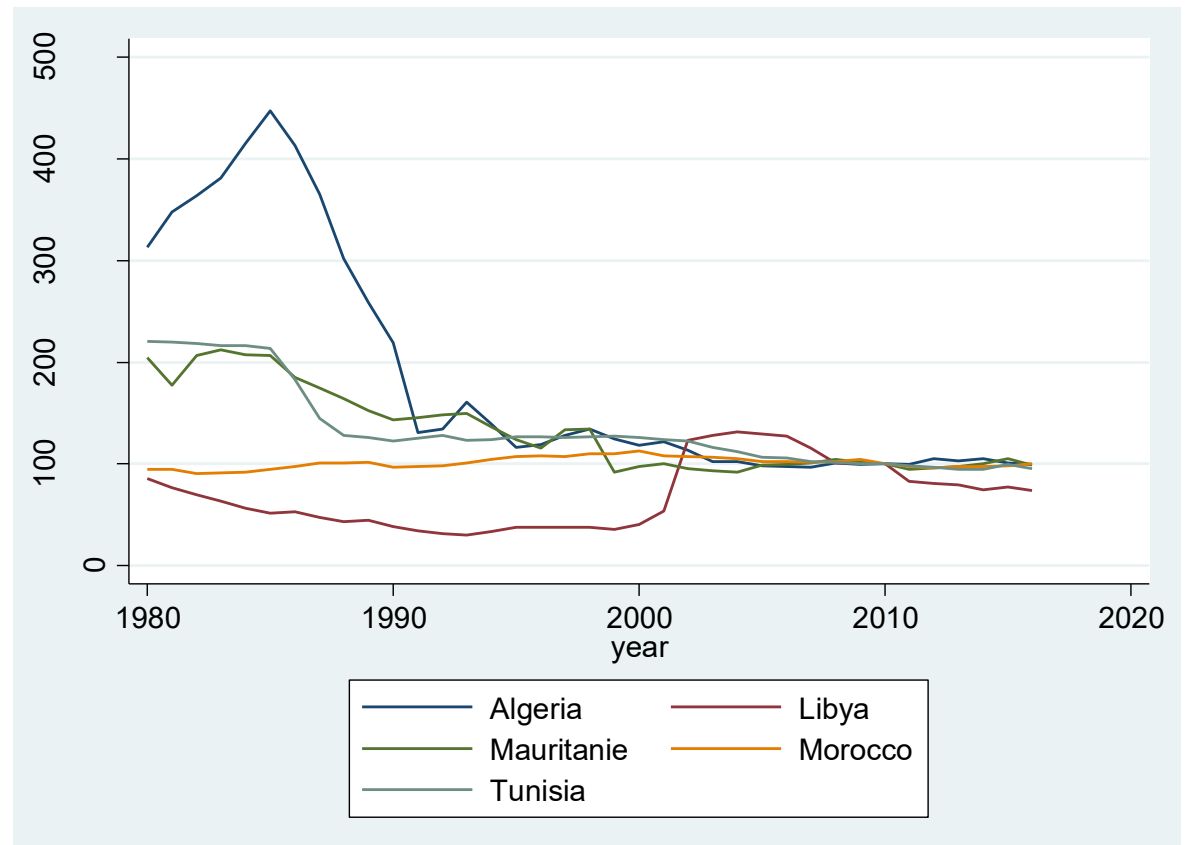

Figure 2. Trend evolution of the REER per country

(Skewness=1.35) and slightly leptokurtic (Kurtosis=0.47). Based on the probability of the Jarque-Bera normality test, authors reject the null hypothesis of normality at $5 \%$. In total, this variable shows a significant overall decrease of $-56.82 \%$ and an annual of $-2.31 \%$.

Overall, authors found that on average, the majority of the series are unstable or in variance, in addition, they show a strong divergence from one country to another, which proves once again the strong heterogeneity and dependence between them.

\subsection{Integration analysis and cointegration test}

The main problems of panel unit root tests are, on the one hand, the form of the heterogeneity of the model used to test stationarity, which is the simplest form as it consists only in postulating the existence of constants specific to each individual and, on the other hand, the possible correlations that may exist between individuals. In fact, taking into account or not these possible inter-individual dependencies opposes two types of generations. Thus, authors present in Table 2 the results Levin, Lin and Chu (2002, LLC), Im, Pesaran and Shin (2003, IPS) and Hadri (2000) panel unit root tests.

Table 2. Unit root tests of variables in logarithm

Source: Author's calculations

\begin{tabular}{|c|c|c|c|c|c|c|}
\hline \multirow{2}{*}{ Variables } & \multicolumn{3}{|c|}{ In level } & \multicolumn{3}{|c|}{ First difference } \\
\hline & LLC & IPS & Hadri & LLC & IPS & Hadri \\
\hline LGDPC & 2.053 & 3.012 & $38.76^{* * *}$ & $-4.360^{* * *}$ & $-7.870^{* \star *}$ & -1.304 \\
\hline LPOP & -1.626 & $-7.121^{\star \star \star}$ & $39.42^{* \star *}$ & $-3.357^{\star *}$ & $-2.617^{\star *}$ & 3.333 \\
\hline LGFCF & 0.625 & 0.064 & $21.42^{\star * \star}$ & $-8.772^{* *}$ & $-8.293^{* * *}$ & -0.859 \\
\hline LFDI & -0.694 & $-2.342^{* * *}$ & $19.39^{* * *}$ & $-5.798^{* * *}$ & $-9.234^{* * \star}$ & -1.418 \\
\hline LREER & $-1.751^{* *}$ & 0.170 & $34.45^{\star \star *}$ & $-5.147^{* * \star}$ & $-5.818^{* * *}$ & 1.261 \\
\hline LCPI & $-3.667^{\star * *}$ & $-5.394^{* * *}$ & $48.27^{\star * \star}$ & $-3.728^{\star \star *}$ & $-3.165^{\star * \star}$ & 1.265 \\
\hline LTRADE & -0.034 & 0.888 & $32.71^{* * *}$ & $-6.767^{\star \star \star}$ & $-7.284^{* * *}$ & -0.467 \\
\hline LM3 & 0.164 & 1.011 & $21.22^{* \star *}$ & $-4.881^{\star \star \star}$ & $-6.909^{* * *}$ & 0.207 \\
\hline LG & -0.118 & -0.794 & $34.85^{* * *}$ & $-5.018^{* * *}$ & $-7.867^{* * *}$ & -0.771 \\
\hline LCREDIT & -0.828 & -0.224 & $26.88^{* * *}$ & $-5.605^{* * *}$ & $-7.093^{* * *}$ & 0.855 \\
\hline
\end{tabular}

Notes: ${ }^{*}, * *$ and ${ }^{* * *}$ significant at $10 \%, 5 \%$ and $1 \%$, respectively. 
From Table 2, all series failed to pass the three units root tests. It is clear then that the Hadri (2000) test is the most relevant because all series show the presence of a unit root in level, while the same series accept the null hypothesis of stationarity in first differences. Thus, it can be consider that all the series are integrated of order 1.

Since the majority of the variables are stationary in first difference, it is important to study the existence of a cointegration relationship between them. Thus, authors have chosen the following step to find out the maximum delay order in a VAR constructed by the 10 variables in question. With reference to the different criteria's, the maximum number of lags chosen is equal to $\mathrm{p}=4$.

Given the large number of variables in the model (10 variables), authors were able to apply only the Kao test (1999) where its ADF statistic $(-1.681$, probability $=0.046)$ rejects the null hypothesis of absence of cointegration for a risk of $5 \%$.

From this descriptive diagnosis and the integration of the different variables of model, authors achieved the important results of the non stability of the variables and the existence of a strong heterogeneity and dependence between the five the Maghreb countries.

\section{ESTIMATES AND INTERPRETATIONS OF THE RESULTS}

In this section, authors test econometric model on the representation the SVECM. Therefore, authors construct a multi-variate vector error-correction model in which the dynamics of growth, the domestic and foreign investment, the exchange rate, the money supply and the price movements are the combined results of the supply and demand shocks.

\subsection{VECM Modeling}

Let a standard VAR be of the following reduced form:

$$
X_{i t}=H_{1} X_{i T-1}+\ldots+H_{k} X_{i t-k}+\mu+e_{i t}
$$

with $\mathrm{t}=1, \ldots, \mathrm{T} ; \mathrm{i}=1, \ldots, \mathrm{N} ; \mathrm{k}$ is the model order (number of delays), $X_{i t}$ is the vector of the model variables. In case, $X_{i t}$ is of dimension $(10 ; 1)$ and defined by

$X_{i t}{ }^{\prime}=[$ LGDPC, LCREDIT, LFDI, LREER, LGFCF, LCPI, LM3, LTRADE, LPOP, LG]. H is a matrix of coefficients, $e_{i t}$ is an error term $(0, \Sigma)$ and $\mu$ is a constant.

In accordance with the Engle and Granger representation theorem (1987), in the presence of a cointegration relation, the standard VAR in the reduced form can be reformulated in an error correction version (VECM):

$$
\Delta X_{i t}=\Gamma+\Delta X_{i t-1}+\ldots+\Gamma_{k-1}+\Delta X_{i t-k+1}+\Pi X_{i t-1}+\mu+e_{i t}
$$

The matrices $\Gamma$ and $\Pi$ contain equations. The first concerns short-term stationary relations, while the second deals with non-stationary long-term relationships. The VAR model representations and its VECM form correspond to the reduced form of the structural VAR presented below:

$$
A(L) X_{i t}=B \varepsilon_{i t}
$$

where $A$ is the polynomial matrix with the delay operator $L, B$ is a diagonal matrix, $\varepsilon_{i t}$ is the vector of orthogonal structural shocks of variance-covariance matrix $\Omega$. Following a series of treatments, come to the following report: 
$\varepsilon_{i t}=C_{0} e_{i t}$

with $\varepsilon_{0}=B^{-1} A_{0}$ and $\Omega=c_{0}^{-1} \sum\left(C_{0}^{-1}\right)$.

The determination of the structural form parameters is possible from the estimated VAR parameters of the reduced form, subject to the imposition of a sufficient number of identification restrictions. These identifying constraints are either long-term or short-term (contemporary relations).

According to the method of Blanchard and Quah (1989), require the imposition of 45 short-term restrictions on the number $[n(n-1) / 2]$ on the structural form or $n=10$. Besides, the identification of the short-term variance-covariance matrix is based on the Choleski method, followed by the identification technique of Bernanke and Mihov (1995). The variance-covariance matrix $\Omega$ contains $[n(n+1) / 2]$ independent restrictions. In case, $\Omega$ provides 55 independent restrictions on the number $[n(n+1) / 2]$.

$\varepsilon$ is the vector of structural innovation that responds to system of which $\varepsilon^{\prime}=\left[\varepsilon_{t}^{G D P C}, \varepsilon_{t}^{C R E D I T}, \varepsilon_{t}^{F D I}, \varepsilon_{t}^{R E E R}, \varepsilon_{t}^{G F C F}, \varepsilon_{t}^{C P I}, \varepsilon_{t}^{M 3}, \varepsilon_{t}^{T R A D E}, \varepsilon_{t}^{P O P}, \varepsilon_{t}^{G}\right]$ are respectively the real supply shock,

the credit supply shock, the foreign investment supply shock, the exchange shock, the domestic investment supply shock, the money demand and supply shock, the trade opening supply shock, the labor demand shock and the public expenditure shock. $e_{i t}$ is the vector of residues in the reduced form:

$e_{t}^{G D P C}, e_{t}^{C R E D I T}, e_{t}^{F D I}, e_{t}^{R E E R}, e_{t}^{G F C F}, e_{t}^{C P I}, e_{t}^{M 3}, e_{t}^{T R A D E}, e_{t}^{P O P}, e_{t}^{G}$, with $C_{0}=B^{-1} A_{0}$.

In reference to the work of Kim (2001), and according to Goux (2006), no over-identification was possible at the B-matrix level, which remains simply diagonal. As a consequence, the shock identification scheme based on the equation of the relationship between structural shocks and reduced-form disturbances is insufficient, i.e. $B \varepsilon_{i t}=A_{0} e_{i t}$.

With reference to the lower triangular shape of the matrix $A_{0}$, competitiveness should respond in the short term to the real supply shock $e_{i t}^{G D P C}$. $H o w e v e r$, authors have considered that, unlike production for domestic consumption, which is immediately affected by a real supply shock (Blanchard \& Quah, 1989), production for foreign markets is not instantaneously influenced by a variation not anticipated from domestic production.

As a result, the external supply of domestic goods and services, and therefore GDPC, does not respond to the real domestic supply shock in the short term, but rather in the long term. In other words, this type of growth shock has no permanent effect on the competitiveness of foreign or domestic investment in the short term. As a result, the growth shock is identified as the only shock that can have a long-term effect on itself. This restriction is justified by the fact that study focuses on small economies the market power of which in the world market is quite limited.

The credit shock has an instantaneous influence on both the external (FDI, REER) and domestic variables (CPI, M3 and G) while the credit reaction function on per capita output is zero, which implies the absence of a credit effect on real domestic production (Citu \& Twanddle, 2003). This manipulation of the theoretical consideration therefore imposes an additional restriction on the non-significant coefficient: $a_{21}=a_{23}=a_{25}=0$.

The FDI shock has a significant impact on the labor force, the exchange rate and the price level. On the other hand, there is no direct relationship with domestic production, which implies the absence of the effect of FDI shocks on real domestic production. This operation of the theoretical consideration therefore imposes the following restrictions: $\mathrm{a}_{31}=\mathrm{a}_{32}=\mathrm{a}_{34}=\mathrm{a}_{35}=\mathrm{a}_{36}=\mathrm{a}_{37}=\mathrm{a}_{38}=\mathrm{a}_{39}=\mathrm{a}_{310}=0$.

The exchange rate shock has an immediate influence on the external variables (FDI, TRADE) as well as the domestic ones, such as GFCF and CPI while the real exchange rate response function on the domestic production index is zero, which implies the absence of the effect of exchange rate shocks on the real domestic production (Citu \& Twanddle, 2003). This leads us to impose additional restrictions on the non-significant coefficient: $\mathrm{a}_{41}=\mathrm{a}_{42}=\mathrm{a}_{43}=\mathrm{a}_{45}=\mathrm{a}_{46}=\mathrm{a}_{48}=\mathrm{a}_{49}=\mathrm{a}_{410}=0$. A domestic investment shock (GFCF) affects only the domestic variables 
(GDPH, M3 and POP), but has no effect on the external ones, which leads us to impose additional restrictions on the non-significant coefficient $\mathrm{a}_{53}=\mathrm{a}_{54}=\mathrm{a}_{510}=0$.

However, according to the contribution of Kim and Roubini (2000), the monetary policy is conducted on the basis of the money supply and the nominal short-term exchange rate. This function implies that the monetary authorities determine the short-term consumer price index based on the values of these two variables (money supply and nominal exchange rate).

Elsewhere, Sims and Zha (1998) argue that monetary policy does not respond instantly to shocks affecting real output or prices. This underlying assumption is authenticated by Peersman and Smets (2001) using the same principle. In fact, the argument lies in the absence of contemporary data on prices and actual output when monetary policy decisions are made. In addition, the lack of immediate short-term CPI response to structural shocks in real supply and demand is particularly relevant for the monetary policy of the Maghreb countries, due to short-term CPI smoothing by the TCB to preserve financial stability. In the context of work, this argument reflects the burden of a constraint of the short-term nullity of the insignificant coefficients: $a_{62}=a_{63}=a_{64}=a_{65}=a_{68}=0$.

This specification implies the nullity of the short-term impact of money supply shocks on both the real output and the real effective exchange rate. Moreover, trade openness is very important for the equilibrium of the trade balance of the Maghreb countries. Notwithstanding, its effect is examined only on short-term domestic production but with no effect on the external variables. This explains that supply and external demand shocks are not affected by shocks to the short-term trade openness. Therefore, get the following restrictions: $\mathrm{a}_{82}=\mathrm{a}_{85}=\mathrm{a}_{810}=0$.

The labor force shock can have an effect only on domestic production and the capital stock. In addition, lower wages in the Maghreb countries encourage foreigners to invest as long as the political and security environment is favorable. Given such conditions, authors propose the following constraints: $a_{92}=a_{94}=a_{96}=a_{97}=0$. Moreover, a consumer spending shock will have a significant effect on economic growth, employment, money supply, CPI and trade openness. Taking into account such conditions, authors allocate the following constraints: $\mathrm{a}_{101}=\mathrm{a}_{103}=\mathrm{a}_{104}=\mathrm{a}_{105}=\mathrm{a}_{108}=0$.

In total, the system consists of the following 10 equations:

$$
\begin{aligned}
& b_{11} \varepsilon_{t}^{G D P C}=e_{t}^{G D P C}+a_{12} e_{t}^{C R E D I T}+a_{13} e_{t}^{F D I}+a_{14} e_{t}^{R E E R}+a_{15} e_{t}^{G F C F}+a_{16} e_{t}^{C P I}+a_{18} e_{t}^{T R A D E}+a_{19} e_{t}^{P O P}+a_{110} e_{t}^{G} ; \\
& b_{22} \varepsilon_{t}^{C R E D I T}=e_{t}^{C R E D I T}+a_{24} e_{t}^{R E E R}+a_{26} e_{t}^{C P I}+a_{27} e_{t}^{M_{3}}+a_{28} e_{t}^{\text {TRADE }}+a_{29} e_{t}^{\text {POP }}+a_{210} e_{t}^{G} ; \\
& b_{33} \varepsilon_{t}^{F D I}=e_{t}^{F D I} \text {; } \\
& b_{44} \varepsilon_{t}^{\text {REER }}=e_{t}^{\text {REER }}+a_{47} e_{t}^{M_{3}} \text {; } \\
& b_{55} \varepsilon_{t}^{G F C F}=a_{51} e_{t}^{G D P C}+a_{52} e_{t}^{C R E D I T}+e_{t}^{G F C F}+a_{56} e_{t}^{C P I}+a_{57} e_{t}^{M_{3}}+a_{58} e_{t}^{T R A D E}+a_{59} e_{t}^{P O P} ; \\
& b_{66} \varepsilon_{t}^{C P I}=a_{61} e_{t}^{G D P C}+e_{t}^{C P I}+a_{67} e_{t}^{M_{3}}+a_{69} e_{t}^{P O P}+a_{610} e_{t}^{G} ; \\
& b_{77} \varepsilon_{t}^{M_{3}}=a_{72} e_{t}^{C R E D I T}+a_{73} e_{t}^{\text {FDI }}+a_{74} e_{t}^{\text {REER }}+a_{75} e_{t}^{G F C F}+e_{t}^{M_{3}}+a_{78} e_{t}^{\text {TRADE }} ; \\
& b_{88} \varepsilon_{t}^{T R A D E}=a_{81} e_{t}^{G D P C}+a_{83} e_{t}^{F D I}+a_{84} e_{t}^{R E E R}+a_{86} e_{t}^{C P I}+e_{t}^{T R A D E}+a_{89} e_{t}^{P O P} ; \\
& b_{99} \varepsilon_{t}^{P O P}=a_{91} e_{t}^{G D P C}+a_{93} e_{t}^{F D I}+a_{95} e_{t}^{G F C F}+a_{98} e_{t}^{T R A D E}+e_{t}^{P O P}+a_{910} e_{t}^{G} ; \\
& b_{1010} \varepsilon_{t}^{G}=a_{102} e_{t}^{C R E D I T}+a_{106} e^{C P I}+a_{107} e_{t}^{M_{3}}+a_{109} e_{t}^{P O P}+e_{t}^{G} .
\end{aligned}
$$

\subsection{Impulse function and variance decomposition}

The decomposition of the variance of forecast errors and the shock response functions are two traditional and relevant exercises that highlight the internal dynamics of a variance system. Table 3 presents the results of the decomposition of the variance of the forecasting error of foreign direct investment (FDI).

Indeed, the foreign direct investment shock contributes about $65 \%$ of its change. This predominance of the foreign direct investment shock persists in both the short and long term. On the other hand, are witnessing weak incremental contributions with close proportions for shocks; real Supply, credit and commercial openness. The most insignificant factor in explaining the variance of FDI is the one attributed to shocks in domestic investment, public expenditure, and money supply to the extent that they never exceed $4 \%$ of GDP of the variability of this variable. 

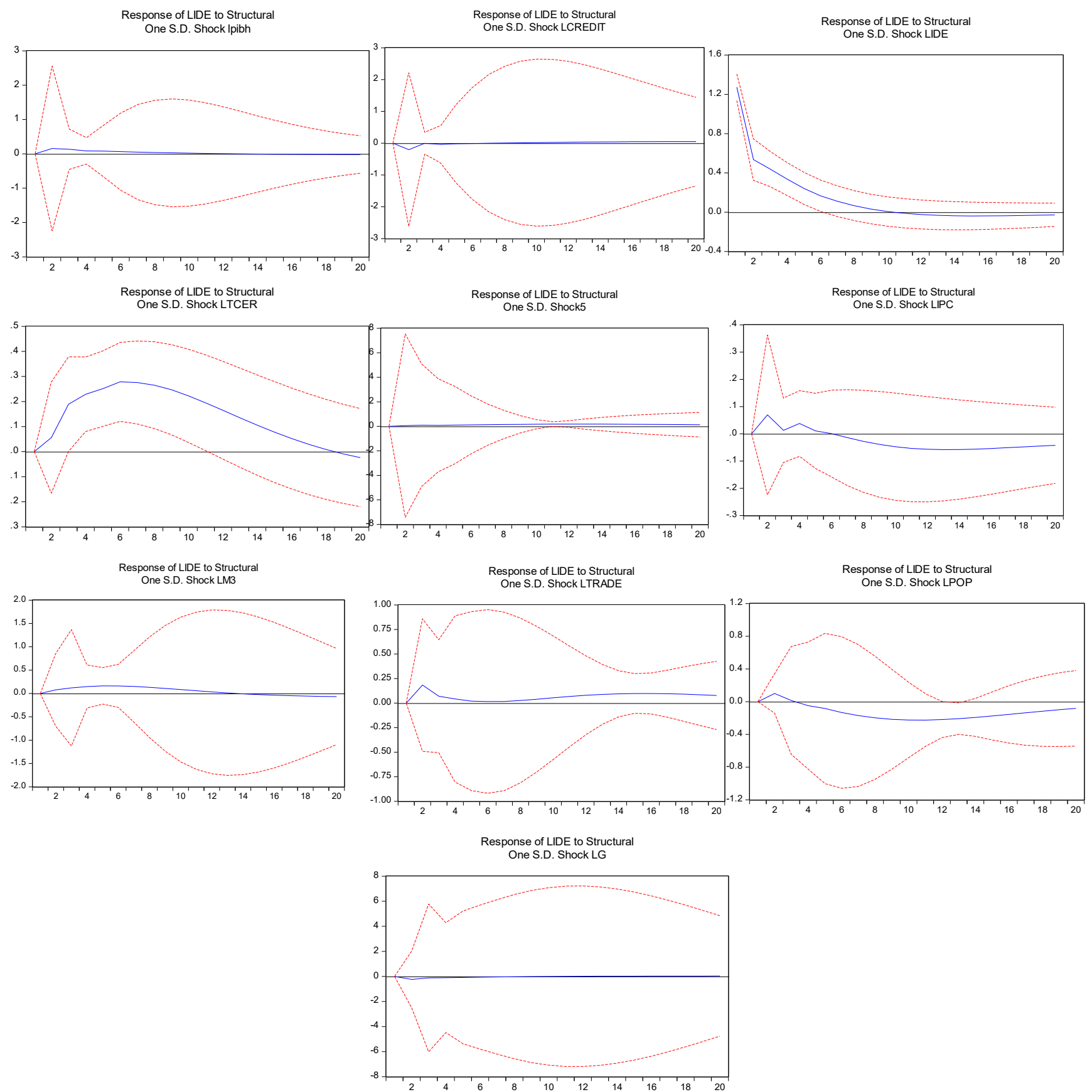

Source: Author's calculations.

Figure 3. Reaction of different shocks to foreign direct investment (FDI) 
Table 3. Decomposition of the Variance of Foreign Direct Investment (FDI)

Source: Author's calculations.

\begin{tabular}{|c|c|c|c|c|c|c|c|c|c|c|}
\hline Period & $\begin{array}{l}\text { Real } \\
\text { Supply } \\
\text { Shock }\end{array}$ & $\begin{array}{l}\text { Credit } \\
\text { Supply } \\
\text { Shock }\end{array}$ & $\begin{array}{c}\text { Foreign } \\
\text { Exchange } \\
\text { Supply } \\
\text { Shock } \\
\end{array}$ & $\begin{array}{l}\text { Exchange } \\
\text { Shock }\end{array}$ & $\begin{array}{c}\text { Domestic } \\
\text { Investment } \\
\text { Supply } \\
\text { Shock } \\
\end{array}$ & $\begin{array}{l}\text { Monetary } \\
\text { Demand } \\
\text { Shock }\end{array}$ & $\begin{array}{l}\text { Monetary } \\
\text { Supply } \\
\text { Shock }\end{array}$ & $\begin{array}{l}\text { Open } \\
\text { Trade } \\
\text { Supply } \\
\text { Shock }\end{array}$ & $\begin{array}{l}\text { Labor } \\
\text { Demand } \\
\text { Shock }\end{array}$ & $\begin{array}{c}\text { Public } \\
\text { Spending } \\
\text { Shock }\end{array}$ \\
\hline 1 & 0.000 & 0.000 & 100.000 & 0.000 & 0.000 & 0.000 & 0.000 & 0.000 & 0.000 & 0.000 \\
\hline 2 & 1.166 & 1.962 & 91.212 & 0.151 & 0.160 & 0.231 & 0.293 & 1.619 & 0.482 & 2.724 \\
\hline 3 & 1.769 & 1.724 & 88.260 & 1.640 & 0.490 & 0.210 & 0.866 & 1.627 & 0.433 & 2.981 \\
\hline 4 & 1.906 & 1.633 & 85.197 & 3.522 & 0.696 & 0.248 & 1.639 & 1.558 & 0.485 & 3.117 \\
\hline 5 & 2.014 & 1.539 & 81.826 & 5.569 & 1.014 & 0.236 & 2.493 & 1.471 & 0.702 & 3.136 \\
\hline 6 & 2.036 & 1.453 & 78.041 & 7.878 & 1.416 & 0.222 & 3.242 & 1.395 & 1.259 & 3.060 \\
\hline 7 & 2.010 & 1.377 & 74.369 & 9.915 & 1.907 & 0.217 & 3.807 & 1.331 & 2.122 & 2.944 \\
\hline 8 & 1.961 & 1.312 & 70.940 & 11.595 & 2.483 & 0.230 & 4.160 & 1.289 & 3.211 & 2.817 \\
\hline 9 & 1.899 & 1.258 & 67.850 & 12.871 & 3.129 & 0.265 & 4.326 & 1.278 & 4.428 & 2.696 \\
\hline 10 & 1.835 & 1.216 & 65.149 & 13.749 & 3.820 & 0.317 & 4.350 & 1.309 & 5.665 & 2.589 \\
\hline
\end{tabular}

The response function of FDI to shocks is shown in Figure 3. The results show that FDI responds to structural shocks in real supply and credit in the same way. The supply shock effect is reflected in the slight but persistent but insignificant increase during the forecasting period. While, the credit shock causes a decrease during the first three years, then it vanishes until the end of the period.

However, authors are interested in the influences of the exchange rate impulses on FDI. Under the assumption of an active transmission power of the nominal exchange rate to FDI, the nominal exchange rate variation leads to a variation of the FDI. Indeed, in the long term, we observe a positive and significant effect of exchange shock until the twentieth forecasting period. Then, this shock vanishes at the end of the period. Finally, the FDI shock response function shows a fairly weak effect of the consumer price index shock on FDI. Indeed, in the long run, the shock effect of FDI is insignificant on the price level.

From the variance decomposition in Table 4, we observe a predominance of external shocks in the explanation of the real effective exchange rate fluctuations. This predominance is mainly attributable to shocks to trade opening, which contributes about $95 \%$ of the exchange rate fluctuations whatever the horizon chosen. For the domestic shocks, results show that their contribution to nominal exchange rate fluctuations remains very limited. Indeed, we find from the variance analysis that the share of the exchange rate variability due to different domestic shocks (real supply, credit, domestic investment, supply and demand, and demand shock of work) hardly exceeds $3 \%$, except in the case of a public expenditure shock of $7 \%$.

Table 4. Variance Decomposition of the Real Effective Exchange Rate (REER)

Source: Author's calculations

\begin{tabular}{|c|c|c|c|c|c|c|c|c|c|c|}
\hline Period & $\begin{array}{c}\text { Real } \\
\text { Supply } \\
\text { Shock }\end{array}$ & $\begin{array}{l}\text { Credit } \\
\text { Supply } \\
\text { Shock }\end{array}$ & $\begin{array}{l}\text { Foreign } \\
\text { Exchange } \\
\text { Supply } \\
\text { Shock }\end{array}$ & $\begin{array}{l}\text { Exchange } \\
\text { Shock }\end{array}$ & $\begin{array}{l}\text { Domestic } \\
\text { Investment } \\
\text { Supply } \\
\text { Shock }\end{array}$ & $\begin{array}{c}\text { Monetary } \\
\text { Demand } \\
\text { Shock }\end{array}$ & $\begin{array}{c}\text { Monetary } \\
\text { Supply } \\
\text { Shock }\end{array}$ & $\begin{array}{l}\text { Open } \\
\text { Trade } \\
\text { Supply } \\
\text { Shock }\end{array}$ & $\begin{array}{l}\text { Labor } \\
\text { Demand } \\
\text { Shock }\end{array}$ & $\begin{array}{l}\text { Public } \\
\text { Spending } \\
\text { Shock }\end{array}$ \\
\hline 1 & 0.103 & 0.028 & 0.237 & 1.094 & 1.134 & 1.926 & 0.363 & 94.448 & 0.060 & 0.606 \\
\hline 2 & 0.212 & 0.058 & 0.138 & 0.709 & 2.966 & 2.045 & 0.168 & 93.171 & 0.027 & 0.506 \\
\hline 3 & 0.369 & 0.071 & 0.283 & 0.794 & 3.592 & 1.957 & 0.264 & 91.677 & 0.026 & 0.967 \\
\hline 4 & 0.442 & 0.148 & 0.389 & 1.100 & 3.780 & 1.973 & 0.468 & 89.891 & 0.079 & 1.731 \\
\hline 5 & 0.482 & 0.294 & 0.495 & 1.356 & 3.784 & 1.982 & 0.746 & 88.064 & 0.182 & 2.616 \\
\hline 6 & 0.498 & 0.502 & 0.603 & 1.603 & 3.690 & 1.980 & 1.067 & 86.190 & 0.320 & 3.547 \\
\hline 7 & 0.497 & 0.769 & 0.715 & 1.869 & 3.542 & 1.972 & 1.403 & 84.266 & 0.495 & 4.472 \\
\hline 8 & 0.487 & 1.088 & 0.827 & 2.154 & 3.365 & 1.959 & 1.733 & 82.319 & 0.711 & 5.357 \\
\hline 9 & 0.471 & 1.454 & 0.936 & 2.458 & 3.179 & 1.939 & 2.046 & 80.364 & 0.972 & 6.182 \\
\hline 10 & 0.451 & 1.858 & 1.037 & 2.780 & 2.997 & 1.913 & 2.336 & 78.408 & 1.286 & 6.933 \\
\hline
\end{tabular}

However, depending on the nature of their shock effects, as presented in Figure 4, it is remarkable that the contribution of external shocks (FDI and TRADE) to the effective exchange rate fluctuations is significant throughout 


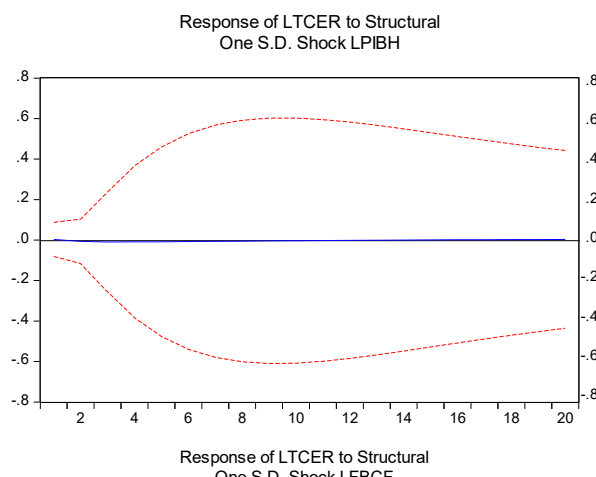

One S.D. Shock LFBCF

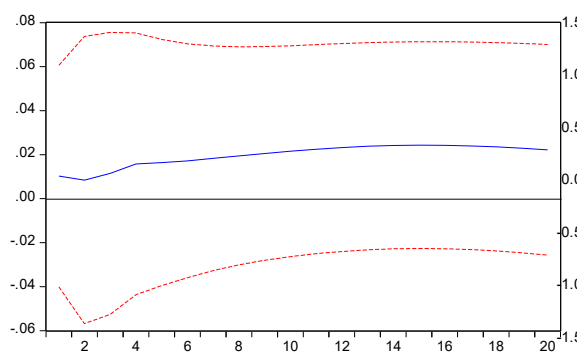

Response of LTCER to Structura

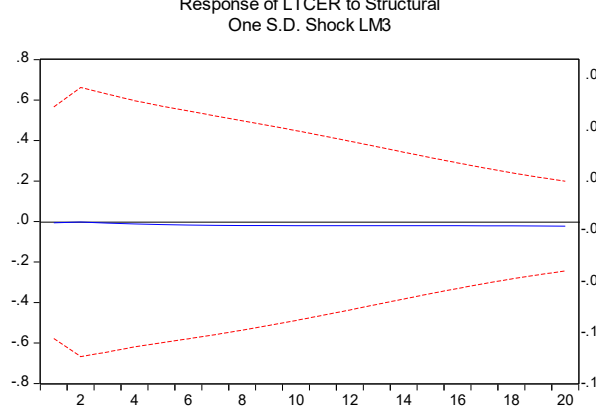

Response of LTCER to Structura One S.D. Shock LCREDIT

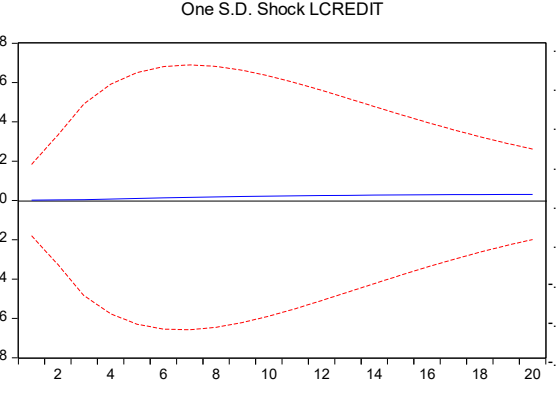

Response of LTCER to Structura

ock LFBCF

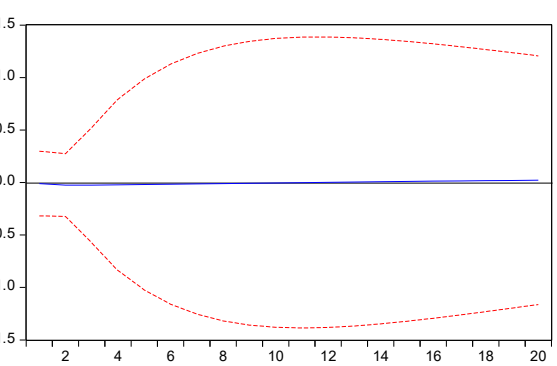

Response of LTCER to Structural
One S.D. Shock LTRADE

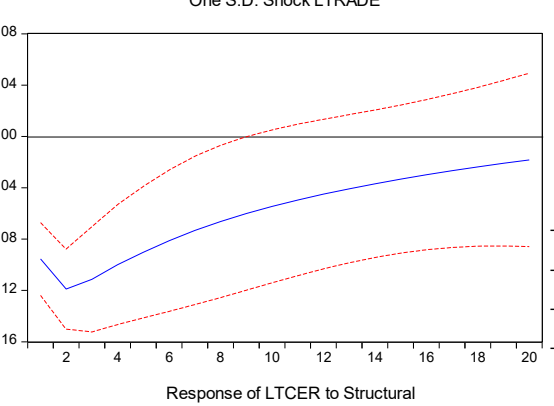

One S.D. Shock LG

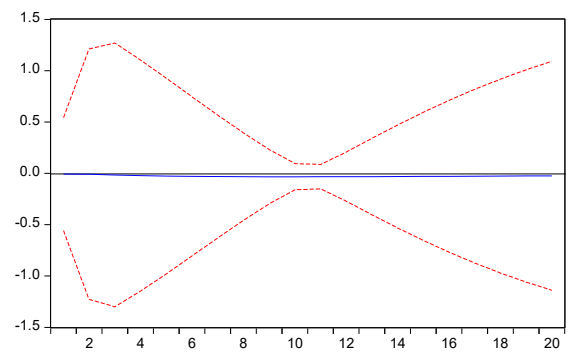

Response of LTCER to Structural One S.D. Shock LIDE

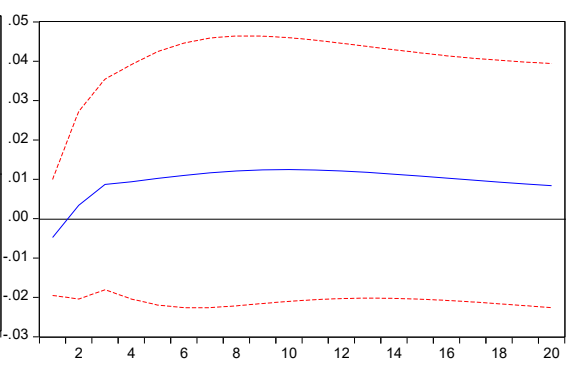

Response of LTCER to Structural

One S.D. Shock LIPC

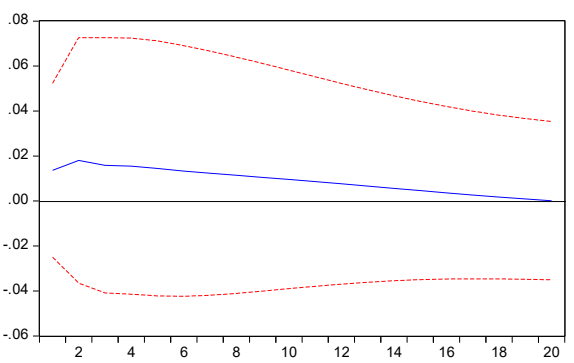

Response of LTCER to Structural
One S.D. Shock LPOP

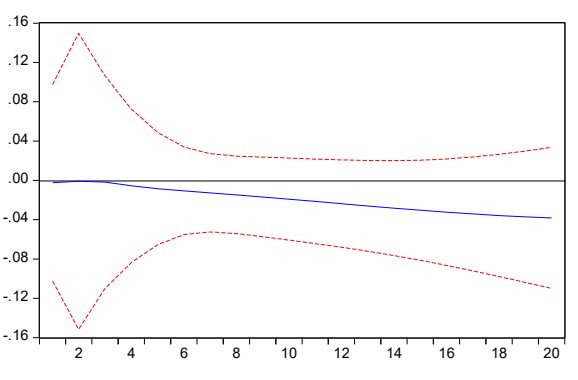

Figure 4. Reaction of different shocks on the exchange rate (REER)

the forecasting period. Indeed, the currency shock responds positively and significantly to the shock of FDI which is negatively affected by the shock of commercial opening.

Regarding the contribution of domestic shocks to the level of the effective exchange rate, the shock response functions revealed a significant effect of the monetary demand shock (CPI) and the domestic investment supply shock (GFCF) on the exchange rate. This result is perfectly consistent with the conclusions drawn from the decomposition of the variance. Indeed, the exchange rate shock response function shows a weak or even a negative effect of the shocks (real supply, credit, money supply and public expenditure) on the long-term exchange rate. 


\section{CONCLUSION}

In this article, authors estimated the dynamic behavior of regional economic activity following real effective exchange rate and FDI shocks using Structural Autoregressive Vector (SVAR) methodology with annual data over the same time interval. In this way, the results of the estimation of these models show a regional dynamic, that is to say that the order of the regions with respect to their respective sensitivity to changes in the real exchange rate is the same. These countries have negative and statistically significant responses, while the responses of economic activity are much weaker and not significant. As with the previous approach, the sensitivity analysis performed on the SVAR models suggests that the results are very robust.

Briefly, authors were able to demonstrate initially that FDI and REER stimulate economic growth in the Maghreb economies in exchange for regime transmutations. In addition, the participation of FDI in socio-economic development seems weakly significant, without the implementation of a policy of support and guidance aimed at reducing the catastrophic effects on the economy and converging its investments towards sectors with high added value. Indeed, the economic privileges of the IDE are indisputable, but are not certain, to bring the maximum benefits of the establishment of foreign firms in the host country. It is essential that firms have appropriate situations that encourage domestic as well as foreign investment that encourage innovation and improve skills, and contribute to a competitive climate.

In addition, the economic growth in Tunisia and Morocco is real despite the fragility of the latter. On the other hand, in Algeria, Mauritania and Libya, the economic development is unreal (fictitious) since it refers to the growth of hydrocarbon exports but not that of products and services (rentier economy). Based on this reality, authors cannot overlook the economic performance achieved in recent years by hydrocarbonate-production countries, such as Algeria.

\section{REFERENCES}

1. Bailliu, J., Lafrance, R., \& Perrault, J.-F. (2001). Exchange Rate Regimes and Economic Growth in Emerging Markets. In Revisiting the Case for Flexible Exchange Rates (pp. 317-345). Proceedings of a conference held by the Bank of Canada (November 2000). Ottawa: Bank of Canada. Retrieved from https://www.bankofcanada.ca/wp-content/uploads/2010/06/baillmure.pdf

2. Bende-Nabende, A. (2002). Foreign Direct Investment in Sub-Sahara Africa: A co-integration analysis. Economics Bulletin, 6(4), 1-19. Retrieved from https://ideas.repec.org/a/ebl/ecbull/eb-02f20002.html

3. Bende-Nabende, A., Ford, J. L, Santoso, B., \& Sen, S. (2003). The interaction between FDI, output and the spillover variables: co-integration and VAR analyses for APEC, 1965-1999. Applied Economic Letters, 10(3), 165-172. https://doi.org/10.1080/1350485022000044057

4. Bernanke, B., \& Mihov, I. (1995). Measuring Monetary Policy (NBER Working Paper, No. 5145). Retrieved from https://econpapers.repec. org/paper/nbrnberwo/5145.htm

5. Blanchard, O. J., \& Quah, D. (1989). The Dynamic Effect of Aggregate Demand and Supply Disturbances (NBER Working Paper No. 2737). American Economic Review, 79(4), 655-673. https://doi.org/10.3386/w2737

6. Burda, M., Bean, C., \& Svejnar, J. (1993). Unemployment, Labour Markets and Structural Change in Eastern Europe. Economic Policy, 8(16), 101-137. https://doi.org/10.2307/1344569

7. Citu, F., \& Twanddle, J. (2003). The Output Gap and it Role in Monetary Policy Decision-making. Reserve Bank of New Zealand Bulletin, 66(1). Retrieved from https://www.rbnz.govt.nz/-/media/ReserveBank/Files/Publications/Bulletins/2003/2003mar66-1citutwaddle.pdf

8. Dabla-Norris, E., Honda, J., Lahreche, A., \& Verdier, G. (2010). FDI Flows to Low-Income Countries: Global Drivers and Growth Implications (IMF Working Paper 10/132). Washington: International Monetary Fund. http://dx.doi.org/10.5089/9781455201150.001

9. Dehejia, V. H. (2003). The choice of monetary/exchange rate regimes: Concepts and arguments (Carleton Economic Papers 03-12). Ottawa: Carleton University. Retrieved from https://ideas.repec.org/p/car/carecp/03-12.html

10. Dehejia, V. H., \& Rowe, N. (1999). Macroeconomic Stabilization: Fixed exchange rates vs inflation targeting vs price level targeting (Carleton Economic Papers 99-15). Ottawa: Carleton University. Retrieved from https://ideas.repec.org/p/car/carecp/99-15.html

11. Engle, R. F., \& Granger, C. W. J. (1987). Co-Integration and Error Correction: Representation, Estimation, and Testing. Econometrica, 55(2), 251-276. http://dx.doi.org/10.2307/1913236

12. Frankel, J. A., \& Romer, D. H. (1999). Does Trade Cause Growth? American Economic Review, 89(3), 379-399. http://dx.doi.org/10.1257/ aer.89.3.379

13. Goux, J. F. (2006). La sensibilité aux chocs économiques de la zone euro. Revue d'économie politique, 116(1), 91-107. Retrieved from https://www.jstor.org/stable/24702492?seq=1

14. Hadri, K. (2000). Testing for Unit Roots in Heterogeneous Panel Data. Econometrics Journal, 3, 148-161. https://doi.org/10.1111/1368423X.00043

15. Husain, A., Mody, A., \& Rogoff, K. S. (2004). Exchange Rate Regime Durability and Performance in Developing Versus Advanced Economies (NBER Working Paper, 10673). https://doi.org/10.3386/w10673 
16. Im, K. S., Pesaran, M. H., \& Shin, Y. (2003). Testing for Unit Roots in Heterogeneous Panels. Journal of Econometrics, 115(1), 53-74. https://doi.org/10.1016/S0304-4076(03)00092-7

17. Kao, Ch. (1999). Spurious Regression and Residual-Based Tests for Cointegration in Panel Data. Journal of Econometrics, 90, 1-44. https://doi.org/10.1016/S0304-4076(98)00023-2

18. Kim, S. (2001). International transmission of the US monetary policy shocks: evidence from VAR's. Journal of Monetary Economics, 48, 339-372. https://doi.org/10.1016/S0304-3932(01)00080-0

19. Kim, S., \& Roubini, N. (2000). Exchange rate anomalies in the industrial countries: a solution with a structural VAR approach. Journal of Monetary Economics, 45(3), 561-586. https://doi.org/10.1016/S0304-3932(00)00010-6

20. Levin, A., Lin, C. F., \& Chu, C. (2002). Unit Root Test in Panel Data: Asymptotic and Finite Sample Properties. Journal of Econometrics, 108, 1-24. https://doi.org/10.1016/S0304-4076(01)00098-7

21. Levy-Yeyati, E. L. E., \& Sturzenegger, F. (2002). Classifying Exchange Rate Regimes: Deeds vs. Words. Retrieved from http://citeseerx.ist.psu. edu/viewdoc/download?doi=10.1.1.32.6688\&rep=rep1\&type $=$ pdf

22. Lipsey, R. (2000). Inward FDI and Economic Growth in Developping Countries. Transnational Corporations, 9(1), 67-95. Retrieved from https://unctad.org/en/Docs/iteiit21v9n1_en.pdf

23. Moon, H. R., \& Perron, B. (2004). Testing for a Unit Root in Panels with Dynamic Factors. Journal of Econometrics, 122, 81-126. https://doi.org/10.1016/j.jeconom.2003.10.020

24. Pahlavani, M., Wilson, E., \& Worthington, A. C. (2005). Trade-GDP Nexus in Iran: An Application of Autoregressive Distributed Lag (ARDL) Model. American Journal of Applied Sciences, 2(7), 1158-1165. http://dx.doi.org/10.3844/ajassp.2005.1158.1165

25. Peersman, G., \& Smets, F. (2001). The Monetary Transmission Mechanism in the Euro Area: More Evidence from VAR Analysis (ECB Working Paper No. 91). Cambridge: Cambridge Univer. Retrieved from https://ssrn.com/abstract=356269

26. Reinhart, C., \& Rogoff, K. (2004). The Modern History of Exchange Rate Arrangements: A Reinterpretation. The Quarterly Journal of Economics, 119(1), 1-48. http://dx.doi.org/10.3386/w8963

27. Selmi, R., Bouoiyour, J., \& Miftah, A. (2016). What Mitigates Economic Growth Volatility in Morocco?: Remittances or FDI. Journal of Economic Integration, 31(1), 65-102. Retrieved from https://www.jstor.org/stable/43739237?seq=1

28. Sims, C., \& Zha, T. (1998). Bayesian Methods for Dynamic Multivariate Models. International Economic Review, 39(4), 949-968. http://dx.doi.org/10.2307/2527347

29. Xu, Z. (2000). Financial Development, Investment, and Economic Growth. Economic Inquiry, 38(2), 331-344.

https://doi. org/10.1111/j.1465-7295.2000.tb00021.x 